Bente Silnes Tandberg, Cand.san., rådgiver ved Barneavdelingen i Vestre viken HF
Frode Kristensen, førstelektor ved Høgskolen i Buskerud og veileder ved Barneavdelingen i Vestre Viken HF

\title{
Bedre samarbeid om praksis
}

\author{
Samarbeid mellom høyskole og barneavdeling førte til økt interesse for og bedre oppfølging av \\ studentene i praksis.
}

H øgskolen i Buskerud og Barneavdelingen Vestre viken HF har samarbeidet om en praksismodell hvor studentene får tematisk veiledning av ressurspersoner og følges opp av en studentkoordinator. Studentkoordinatoren deltar på evalueringer og ukentlige grupperefleksjoner.

\begin{abstract}
Bakgrunn
Dette prosjektet er et klinisk praktisk prosjekt. Hensikten var å utvikle en modell for oppfølging av sykepleierstudenter når de er i klinisk praksis på Barneavdelingen. Bachelorstudentens praksis forgår på en barnemedisinsk enhet, som også inkluderer barnepoliklinikk, dagbehandlingseksjon og eget barnemottak. Sykdomsbildet på barneavdelingen er mangfoldig; studentene møter både akutt og kronisk syke barn og deres familier.

Vi ønsket at modellen skulle ivareta informasjonsutveksling og samarbeid mellom praksisfelt og høyskolen. To studentkoordinatorer fungerte som et bindeledd og hadde ansvar for oppfølging av alle studentene i praksisforløpet. Høyskolens veileder var til stede på velkomstmøtet, samt på midt- og sluttvurdering og de fleste kliniske refleksjonsmøtene. Studentene fikk tematisk veiledning på kompetanseområder fra ressurspersoner som ble supplert med veiledning fra studentkoordinatorene.
\end{abstract}

\section{Hovedbudskap}

Prosjektet har økt samarbeidet mellom høyskolen og praksis. Økt vekt på veiledning har medført et bredere engasjement for studenter i praksis. Prosjektet har bidratt til å utvikle et mer kritisk blikk på praksisveiledningens kvalitet på Barneavdelingen.

\section{Nøkkelord}

Les mer og finn litteraturhenvisninger på våre nettsider. ) Evaluering | Veiledning | Barn / Sykepleiestudenter / Sykepleierutdanning
Før prosjektstart opplevde Barneavdelingen et økende påtrykk om å tilby kirurgisk praksis for studenter. Derfor vektla vi erfaringer med å gjennomføre kirurgisk praksis på en barneavdeling i prosjektet. I kirurgisk praksis vil temaer som pre- og postoperativ sykepleie, smertevurdering og behandling vies spesiell oppmerksomhet.

\section{Tenke nytt}

I forbindelse med Osloprosessen ble driften ved Barneavdelingen omorganisert. Den nye organiseringen gjorde at vi tenkte nytt om flere forhold. Driften ble betydelig effektivisert ved at mange av barnepasientene ble overført fra døgn- til dagbehandling. Det er stort arbeidspress for sykepleierne ved de ulike seksjonene, som alle mottar pasienter som trenger øyeblikkelig hjelp. Kompetansen er spesialisert, og de ansatte opplever at de inneliggende pasientene er stadig sykere. Studentene møter familier i en utfordrende livssituasjon og pasienter med svært ulike sykdommer. I tillegg møter de barn på vidt forskjellig utviklingstrinn. Dette øker kravene til gode rutiner for oppfølging av studentene, samt kompetansekrav knyttet til informasjon og veiledning av pasientene.

\section{Sårbart system}

Veiledning i praksis er styrt av lover og avtaler. Mangel på ressurser kan gjøre det vanskelig for den enkelte kontaktsykepleier å ha kontinuerlig oversikt over læreplaner og krav til læringsutbytte. Frem til prosjektstart hadde Barneavdelingen pålagt den enkelte kontaktsykepleier det daglige ansvaret for veiledning og opplæring av studenter. Dette medførte at veiledningen av den enkelte student kunne bli tilfeldig. Systemet var sårbart, dersom kontaktsykepleier for eksempel byttet vakter eller ble syk. I en spørreundersøkelse identifiserte studentene tid, stress samt mangel på organisert opplæring og kontaktsykepleiers manglende tilgjengelighet som barrierer for læring (1). Bjerkvold og Sørlie framhever tid til refleksjon som en nødvendig forutsetning for målrettet læring (2). Bjørk har gjort en analyse av hvordan sykehusavdelinger fungerer som læringsmiljø for nyutdannete sykepleiere. Hun påpeker at avklaring av roller og en overordnet forståelse for betydningen av kompetanseutvikling er nødvendig for å skape gode læringsmiljøer (3). Kvalifisert veiledning og gode læringssituasjoner er en forutsetning for den nyansattes vekst og utvikling. Det samme framholder Caspersen, som har undersøkt kvalifisering av nyutdannete sykepleiere. Hans undersøkelse viser at systematisk veiledning fra en overordnet eller kollega har en sterk positiv effekt (4). En evalueringsstudie som inkluderer studenter, lærere og praksisveiledere viste at bachelorstudenters relasjon til veilederen betyr mye for bachelorstudenten når de er i sykehuspraksis (5).

\section{Andre prosjekter}

Vi er kjent med at også andre sykehus og høyskoler har samarbeidet om å endre praksisstudier for sykepleierstudenter. Ved Helgelandsykehuset i Mo i Rana og Høgskolen i Bodø har man jobbet strukturert med brobygging mellom praksisfelt og høyskole. I evalueringen ble det kollektive veiledningsansvaret vektlagt (6). Et tilsvarende prosjekt pågår mellom kvinne- og barneklinikken Oslo universitetssykehus og Høgskolen i Oslo, men dette er ikke publisert. Sykehuset Innlandet startet barneavdelingen med å standardisere innholdet for veiledning av studentene fra Høgskolen i Gjøvik; en progresjonsplan med gradvis økning av ansvar basert på læring- og ferdighetstrening. Tilsvarende har vi i dette prosjektet utarbeidet en progresjonsplanfor studentens praksis på barneavdelingen, en progresjonsplan med gradvis økning av ansvar basert på læring- og ferdighetstrening. Progresjonsplanen ble utviklet på bakgrunn av gjennomgang av teori og høringsrunder med sentrale fagpersoner i praksis (fagutviklingssykepleiere og ledere) samt høyskolens læringsplan 


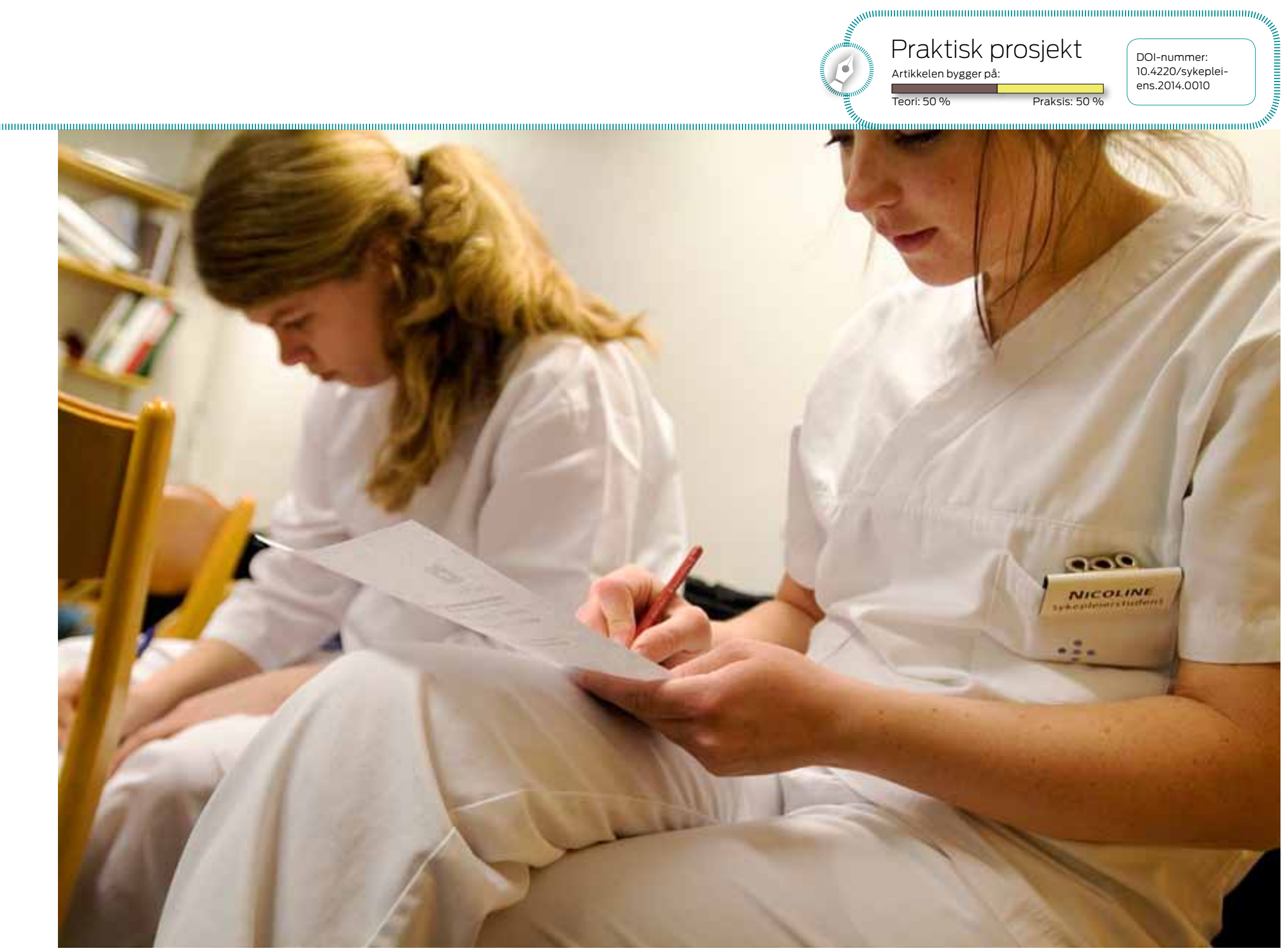

FORNøYDE STUDENTER: Ukentlige evalueringssamlinger hvor studentene i fellesskap kunne reflektere over praksis ble sett på som positivt av de fleste studentene. Illustrasjonsfoto: Stig Weston.

for kliniske studier. Planen erstatter ikke skolens læreplan eller studentenes arbeidsplan. Progresjonsplanen blir presentert og gjennomgått for studentene ved oppstart i avdelingen. Planen inneholder generelle læringsmål knyttet til ulike tema, for eksempel medikamenthåndtering og spesifikke læringsmål knyttet til de ulike seksjonene hvor studentene har praksis, som mottak og dagenhet

\section{Veiledningskurs}

Barneavdelingen vår hadde et generelt behov for å øke veiledningskompetansen. En vesentlig del av prosjektet innebar derfor veiledning og oppfølging av ressurspersonene. I tillegg ble det lagt til rette for å delta på veiledningskurs arrangert av høyskolen. Fem av elleve ressurspersoner har vært på veiledningskurs. I tillegg fikk prosjektet midler til frikjøp av førstelektor ved høyskolen (18 timer) til direkte veiledning av ressurspersoner og praksiskoordinatorer i klinisk praksis. Timene ble fordelt på totimers samlinger gjennom prosjektperioden. Hensikten med samlingene var flere - primært å bidra til en tettere dialog mellom høyskole og praksisfelt med gjensidig læringsutbytte, samt $ø$ ke sykepleiernes veiledningskompetanse. Prosjektet skulle også evalueres underveis med tanke på forbedringsmuligheter. Samlingene med veileder fra høyskolen inneholdt oftest en miniforelesning på 5-10 minutter knyttet til relevante situasjoner eller utfordringer ressurspersonene møtte i veiledning og praktisk arbeid. Temaet kunne være konflikt og konfliktløsning, personlige egenskaper i møtet med studenten og muligheter for vekst og utvikling. Angst og usikkerhet som hinder for konstruktiv veiledning var også oppe som tema. Ressurspersonenes erfaringer dannet grunnlag for diskusjon og innspill i plenum.

\section{Metode}

Studenter $(n=24)$ har evaluert prosjektet i tre grupper ved hjelp av spørreskjema. Spørreskjemaet bygger på et skjema fra prosjektet ved høgskolen på Gjøvik (7). Enkelte spørsmål ble omformulert for å tilpasses dette spesifikke prosjekt. Vi innhentet formell tillatelse til å bruke det. I tillegg har ressurspersoner og studenter deltatt på gruppebaserte evalueringssamlinger.

I behandling av spørreskjemaet benyttet vi SPPS versjon 18 for behandling av tallmaterialet med beskrivende statistikk med frekvensanalyser. Tekstmaterialet fra spørreskjema samt notater fra evalueringssamlinger er gjennomgått og kategorisert.

\section{«Det har vært litt vanskelig når man møter nye syke- pleiere nesten hver uke.॥}

Alle studentene ( $\mathrm{n}=24)$ som deltok i prosjektet, deltok på evalueringssamling og har besvart spørreskjemaet. På grunn av vaktbelastning varierte ressurspersonenes deltakelse på samlingene noe.

\section{Evaluering}

Evalueringssamlingene ble ledet av prosjektleder som ellers bare hadde møtt studentene ved første velkomstsamling. Hensikten var at studentene i fellesskap skulle komme frem til en konsis og utfyllende tilbakemelding om modellens funksjonalitet for studentenes læring i praksis.

Samlingen ble innledet med en runde hvor alle uttalte seg. I etterkant av runden kommenterte studentene hverandres uttalelser og supplerte med egne erfaringer. Leder av samlingen 
lot samtalen mellom studentene løpe fritt, og noterte ned tilbakemeldinger som ble gjentatt av flere studenter. Alle studentene hadde lært mye om klinisk observasjon av grunnleggende behov ved å ha praksis på barnemottak. Andre viktige erfaringer var at enkelte studenter hadde opplevd å gå alene uten fast veileder.

Evalueringssamlingene har også vært viktige for å avslutte praksis for studentene på en god og ryddig måte. Spørreskjemaet inneholder spørsmål om ansvar for og administrering av egen læring, refleksjon og samarbeid. Etter første studentgruppe og med utgangspunkt i deres evaluering ble spørreskjemaet supplert med teorispørsmål. Spørreskjemaet inneholder spørsmål som; «Hvilket utbytte fikk du av teoridagen?», der svaralternativene er graderte i: Meget bra, bra, mindre bra, dårlig. Men skjemaet inneholder også spørsmål som krever at studentene begrunner svarene sine. Avslutningsvis var det også et par åpne spørsmål som: «Nevn forhold i denne praksisperioden som var viktige for deg i forhold til tidligere praksisperioder?» samt to tilleggsspørsmål for studenter i kirurgisk praksis om hvordan læringsutbytte hadde vært knyttet til kirurgi.

\section{Ansvar for egen læring}

Modellen gir studenten stor frihet til å organisere sin egen læring i praksis. Tidligere fulgte studentene en kontaktsykepleier slik at læringssituasjonene oppsto tilfeldig ettersom hvilke pasienter kontaktsykepleieren hadde ansvar for. I denne modellen kan studentene velge å følge et pasientforløp eller oppsøke spesielle læringssituasjoner uten å være avhengige av å følge en enkeltperson. Med denne friheten følger ansvar. Haugan et al. (8) fant at studenter beskrev praksishverdagen

\section{«Det er jo lettere å snakke med medstudenter om læringssituasjoner, da de selv er i samme situasjon»».}

som i stor grad styrt av relasjonen mellom dem selv og veilederen. De snakket lite om hvordan de selv kunne påvirke denne relasjonen. Våre studenter blir pålagt et betydelig ansvar for egen læring uten at de har en fast veileder å lene seg mot. For de studentene som er rustet til et slikt ansvaret er friheten modellen gir et stort pluss: «Det at jeg har tatt ansvar for egen læring har ført til at jeg har nådd målene jeg har satt opp».

Mangel på en fast veileder er modellens svake
Hvilket læringsutbytte har studenten hatt av ukentlige refleksjonsmøter i avdelingen?

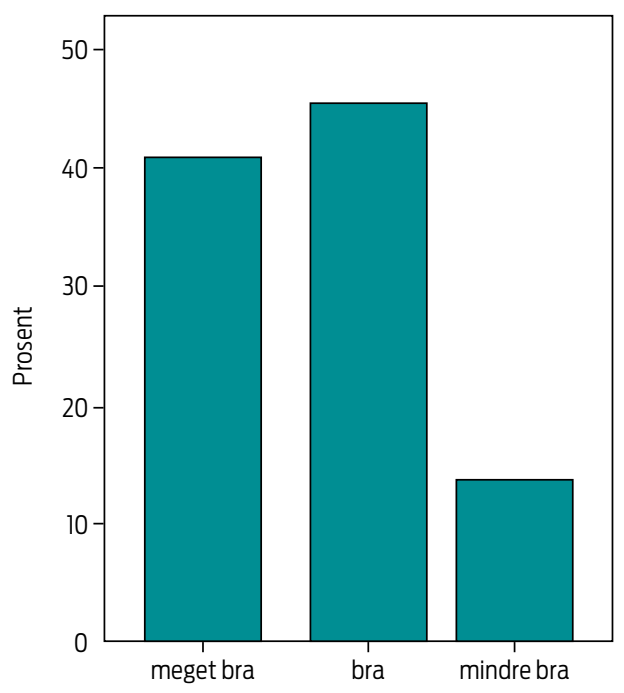

FIGUR 1: Læringsutbytte ved ukentlige refleksjonsmøter

punkt. Studenter som sliter med og å nå læringsmål, særlig i første praksisperiode, savner en fast kontakt som guider dem i læringssituasjoner og som framstår som profesjonelle forbilder: «Det har vært litt vanskelig når man møter nye sykepleiere nesten hver uke», uttalte en av dem.

\section{Veilederrollen}

Haugan et al. (8) fant at det medansvaret studenter fikk i ulike pasientsituasjoner var avhengig av den enkelte veileders vurdering, som igjen var basert på et tillitsforhold. Våre studenter går med ulike ressurspersoner og har begrenset mulighet til å opparbeide tillit hos sine veiledere. De må derfor selv aktivt oppsøke ressurspersonene og sette ord på egne ferdigheter og læringsbehov for å få ansvar. Studentene ble oppfordret til å bruke progresjonsplanen som et dialogredskap med sykepleierne for å gi dem innsikt i egen læringsprogresjon. Studenten rapporterte jevnt over om god kontakt med og veiledning fra ressurspersoner (se figur 2).

En annen del av studien til Haugans et al. (4) tok for seg praksisveilederes erfaringer med å veilede bachelorstudenter, og fant at sykepleierne ofte føler seg usikre i veilederrollen. Mangel på tid til å gjøre seg kjent med studiets mål og innhold samt opplevelse av rollekonflikt når de skulle etablere relasjon til pasient og student samtidig, ble oppgitt som årsak (5). De som skulle veilede studentene i vårt prosjekt savnet også en fast veilederrelasjon, særlig
Hvordan har studenten opplevd kontakt og veiledning med ressurspersonene?

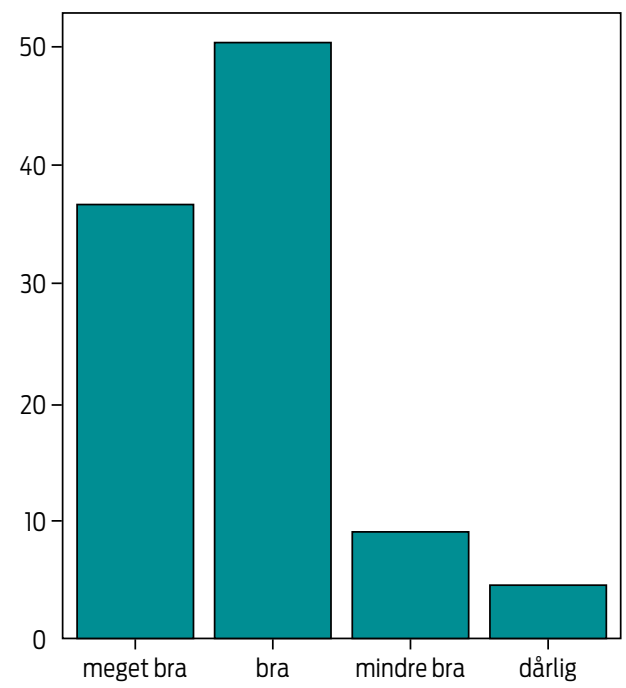

FIGUR 2: Kontakt og veiledning med ressurspersoner

i de tilfellene hvor de var usikre på studentens kompetanse. Det betyr at ressurspersonene må gi studentene medansvar uten alltid å ha full kontroll over ferdighetene deres. Det var ikke ressurspersonenes ansvar å evaluere studentene til midt- og sluttvurdering. Dette ble gjennomført av studentkoordinatorene og høyskolens veileder. Studentkoordinatorene innhentet tilstrekkelig kjennskap til studentens progresjon gjennom veiledningsmøtene med studenter og ressurspersoner, og rapporterte ikke manglende innsikt i studentens læring som en utfordring.

\section{Læringsutbytte}

Studentene rapporterer at de fikk reflektert mye på ukentlige veiledningsmøter (fig. 1) og i mer varierende grad med ressurspersoner (fig. 2). Eksempelvis var det bare fire studenter som rapporterte at de hadde diskutert arbeidskrav med en av ressurspersonene. Samtidig var det bare en student som rapporterte at kontakten med ressurspersoner hadde vært dårlig, mens to studenter rapporterte kontakten som mindre bra.

Studentene rapporterer imidlertid at de har hatt god mulighet til refleksjon med medstudenter. Kun en student oppgir at vedkommende i liten grad har reflektert med medstudenter. Det synes å være en forbindelse mellom effekten av gruppeveiledning og sykepleiestudentens personlige vekst og utvikling av profesjonell identitet. Dette indikerer at refleksjon er en måte å minske gapet mellom teori og praksis på (9): 
«Det er jo lettere å snakke med medstudenter om læringssituasjoner, da de selv er i samme situasjon», uttalte en av studentene.

I studien til Kangasniemi, Ahonen, Likanen og Utriainen (10) beskrives veiledning fra andre gruppemedlemmer. Studentene mener det er viktig med veiledning fra medstudenter fordi de befinner seg i samme situasjon og har de samme utfordringene. Ifølge studentene kommer de viktigste bidragene fra medstudenter.

\section{Refleksjonsmøter}

Studentens praksis var basert på «learning by doing» med konkret og direkte veiledning i å utføre oppgaver. Diskusjon og veiledning knyttet til faglig utvikling og holdning ble i stor grad utført på de ukentlige, faste veiledningsmøtene med studentkoordinatorene og skolens veileder. Studentene evaluerte denne formen for gruppeveiledning positivt. 19 av 24 rapporterte svært bra eller bra utbytte og påpekte at dette også ga rom for studentrefleksjon: «En blir mer bevisst på hva en kan og ikke kan, samtidig som en får utbytte av forskjellige synsvinkler fra lærer, koordinator samt medstudenter».

På de ukentlige refleksjonsmøtene ble studentene oppfordret til å fortelle om situasjoner de hadde vært i siden sist. Noen studenter opplevde settingen som krevende. Studentgruppen fungerte best i andre og tredje periode. Dette samsvarer med resultatene fra Arvidsson et al. (8) hvor gruppeveiledningene ble gjennomført etter klare regler basert på gjensidig tillit mellom veileder og studenter. Sentrale faktorer var kontinuitet, fortrolighet og respekt. Studentene ble invitert til å stå fram og beskrive en valgt omsorgsrelatert situasjon. I etterkant stilte gruppemedlemmene spørsmål om tanker, handlinger, følelser og erfaringer relatert til situasjonen (9): «Altfor mye om hva som har skjedd, er ikke alltid en har så mye å si. En blir fort 〈grillet〉 med masse spørsmål og føler seg dum når en ikke kan svare», beskrev en.

Over 70 prosent av studentene evaluerte progresjonsplanen som et nyttig verktøy. Den ble benyttet av studentene og ressurspersonene som arbeidsredskap, både for å utvikle selvstendige læringsmål og som et kommunikasjonsverktøy med ressurspersoner. Forenklet kan man si at progresjonsplanen hjelper både student og ressurspersoner til å «beholde retningen» gjennom studentens praksisperiode: «Progresjonsplanen har vært en kjempestor hjelp. Har fulgt den, og veldig bra at de ulike avdelingene har et innblikk i den også», skrev en av studentene.

\section{Samarbeid}

Dette prosjektet har økt samarbeidet mellom høyskolen og praksis. Studentene var i stor grad tilfredse med informasjon fra høyskolen, 21 studenter er meget fornøyde eller fornøyde og tilsvarende antall er også meget fornøyde med veiledning fra lærer. I første praksisperiode hadde studentene stort sett kun kontakt med praksiskoordinatorene.

Etter evaluering med den første gruppen av studenter ble det gjort en endring fra skolens side med vekt på hyppigere tilstedeværelse på refleksjonsmøtene og tettere oppfølging: «Jeg opplever å ha blitt fulgt godt opp fra lærer og synes også det har gitt en trygghet som student å ha en god og åpen relasjon».

\section{Kirurgisk praksis}

På Barneavdelingen ligger det til enhver tid noen få kirurgiske pasienter. De får utført «småkirurgi» som øre-nese-hals og noe ortopedi. Vi var bekymret for om barneavdelingen klarte å framskaffe nok gode læresituasjoner for studenter i kirurgisk praksis. Vi hadde tre studenter i kirurgisk praksis i hver studentperiode. Alle kirurgiske pasienter ble øremerket til studenter i kirurgisk praksis, og noen ressurspersoner med særlig interesse for kirurgi var «kirurgiressurser». Antallet kirurgiske pasienter er såpass lite at studentene ofte måtte gå sammen om pasientene. I tillegg var kirurgipasientene karakterisert som «enkle» pasienter som ofte ble fordelt til erfarne hjelpepleiere. Samtidig var de kirurgiske studentene tilfredse med å kunne følge kirurgiske pasientene gjennom hele forløpet - på operasjonsstuen og postoperativ. Kirurgi ble også viet særlig oppmerksomhet på de ukentlige veiledningssamlingene med studentene. Med utgangspunkt i en fagartikkel ble problemstillinger knyttet til den pediatriske kirurgipasienten diskutert (11). Preoperative forberedelser og smerte er i så måte særlig relevante temaer, som var gjenstand for diskusjon og engasjement. Praksiskoordinatorene og ressurspersoner har i prosjektet sett at den «sultne», modne eller voksne studenten klarer å få innsikt i de tre ulike fasene pre-, per- og postoperativ, men at yngre og uerfarne studenter sliter mer med dette: «Veldig bra, men tidvis for mange studenter på for få pasienter» og: «Blitt tryggere på den sykepleien som kreves pre- og postoperativt», var to av tilbakemeldingene.

Dette samsvarer med generelle erfaringer fra modellen. Den aktive studenten vokser og trives gjennom ukentlige veiledningsgrupper. Indre motivasjon og nysgjerrighet på læring trigges under ansvar. Noen trekker frem friheten til å kunne velge: «Jeg har kunnet velge hvilke læresituasjoner jeg ønsket å være med i, og ikke minst ta valg ut fra hva jeg har hatt fokus på». Studenter som svarer slik får antakeligvis læringsutbytte i praksis uavhengig av modell.

\section{Avslutning}

VVHF har valgt å implementere modellen. Vi fortsetter å ta imot studenter med kirurgisk praksis, men ser det ikke som hensiktsmessig å $ø$ ke antallet kirurgiske plasser. Suksesskriterier er særlig knyttet opp mot at vi nå kommuniserer forventninger og gir god informasjon om praksisfeltet i forkant av praksisstudiene. Videre har praksisplanen medført en standardisering av innhold med klare planer og tydelige mål som både studenter, ressurspersoner og lærer er godt kjent med. Vi har også sett at det er nødvendig å styrke oppfølgingen av den enkelte student ved at studentene nå blir fordelt til en fast gruppe ressurspersoner. Enkelte studenter har behov for hjelp til å se de gode læresituasjonene. Dette gjelder naturlig nok særlig studentene i første praksisperiode. Prosjektet har hjulpet oss bort fra tilfeldig praksis og over til å utvikle et mer kritisk blikk på at praksisveiledning på Barneavdelingen skal være av god kvalitet. IIII

Forfatterne takker alle studenter og ressurspersoner som har deltatt i prosjektet, og en scrlig takk rettes til Nancy Dahlberg, Anette Bjørnstad, Silje Løver Aukrust og Therese Hjalming Moen.

\section{REFERANSER}

Daisy KM. Læringsbarrierer iklinisk praksis. Sykepleien 2003; 8: 40-46.

2. Bjerkvold MPM, Sørlie ABK. Utdanning/pedagogikk: Alternativ praksismodell. Sykepleien 2003; 17:39-42.

3. Bjørk IT. Sykehusavdelingen - et miljø for læring? Vård i Norden 2001; 1:4-9.

4. Caspersen J. Kvalifisering av nyutdannete sykepleiere - en undersøkelse av læringsstrategier og opplæring i arbeidslivet. Høgskolen i Oslo: Senter for profesjonsstudier, HIO-rapport. nr. 12, 2007.

5. Aigelteiger $E H$, Haugan G, Sørlie V. Utfordringer med å veilede sykepleiestudenter i praksisstudier. Sykepleien forskning 2012; 7(2):160-166.

6. Lunestad ROT. Dumå være på hugget som sykepleiestudent for ålære i praksis. Enny modell for veiledning i sykehuspraksis. Nordisk Tidsskrift for Helseforskning 2007; 2: (3) $110-119$

7. Kleiven, I. F., Jøndal, S. \& Snilsberg, L. M. (2010). Studenttett post med fokus på kunnskapsbasert praksis: Videreutvikling av modellen «Studenttettpost).

Haugan G, Aigeltinger E, Sørlie V. (2012). Relasjonen til veilederen betyr mye for sykepleierstudenter i sykehuspraksis. Sykepleien Forskning 2012; 2(7): 152-159.

10. Arvidsson B, Baigi A, Skärsäter I. Changes in the effects of process-oriented group supervision as reported by female and male nursing students: a prospective longitudinal study. Scand J Caring Sci 2008:22: 437-444.

11. Kangasniemi M, Ahonen SM, Likanen E, Utriainen K. Health science students' conceptions of group supervision. Nurse Education Today 2011; 31: $179-183$.

12. Ireland D. Unique concerns of the pediatric surgical patient: pre-, intra-, and postoperatively. The Nursing clinics of North America 2006; 41(2): 265-98.

Fagartikler kan sendes til torhild.apall@sykepleien.no 